\author{
St ud i P hilos o p h i c a \\ Wr a t i s l a vi e n s i a \\ vol. XIII, fasc. 4 (2018) \\ DOI: $10.19195 / 1895-8001.13 .4 .2$
}

\author{
DANUTA ŚLĘCZEK-CZAKON \\ ORCID: 0000-0001-6231-3449 \\ Uniwersytet Śląski w Katowicach
}

\title{
Pojęcie jakości życia. Aspekt medyczny i bioetyczny
}

Pojęcie jakości życia pojawiło się po II wojnie światowej w Stanach Zjednoczonych i krajach Europy Zachodniej ${ }^{1}$. Początkowo służyło ono do analiz sytuacji społeczno-ekonomicznej i określenia poziomu rozwoju cywilizacji. Obecne w takich naukach, jak: socjologia, ekonomia, psychologia, historia, geografia, pojęcie to obejmowało dobra materialne przypadające na mieszkańca (PKB, liczba samochodów, mieszkań, standard wyposażenia mieszkań, ilość pieniędzy przeznaczonych na emerytury, opiekę zdrowotną). W latach sześćdziesiątych rozszerzono zakres tego terminu — objęto nim również wykształcenie, zakres wolności osobistej, satysfakcję z różnych sfer życia, a także negatywne wskaźniki życia społecznego (przestępczość, alkoholizm). Pojęcie jakości życia początkowo zawierało głównie wskaźniki obiektywne (ekonomiczne), potem włączono do niego wskaźniki subiektywne (ocenę jakości życia z punktu widzenia osobistych doświadczeń, samopoczucia, porównania poziomu swojego życia z normami społecznymi w zakresie konsumpcji, sukcesu życiowego, prestiżu).

\section{Jakość życia w medycynie}

Przeniesione (od lat siedemdziesiątych XX wieku) z nauk społecznych do medycyny pojęcie jakości życia było wyrazem nowego modelu w podejściu do człowieka chorego — oprócz przedłużania życia istotne stało się, aby to życie było zbliżone do obowiązujących standardów, aby jak najbardziej przypominało życie aktywnych, zdrowych ludzi. Na terenie medycyny pojęcie jakości życia związane jest z pojmowaniem zdrowia, choroby i nieuchronnymi procesami starzenia sie,

${ }^{1}$ B. Tobiasz-Adamczyk, Jakość życia w naukach społecznych i medycynie, ,Sztuka Leczenia” 2 (1996), s. $33-40$. 
dlatego stosuje się termin Health-related quality of life (HRQoL). W ocenie jakości życia stosuje się wskaźniki obiektywne (stan zdrowia człowieka i jego status społeczno-ekonomiczny) i subiektywne (satysfakcja z życia i sposób postrzegania siebie). Zarówno w naukach społecznych, jak i medycznych trwa dyskusja na temat tego, czy możliwe jest opracowanie jednej, powszechnej i stosowanej w wielu dyscyplinach naukowych definicji jakości życia².

Pojęcie jakości życia ma charakter holistyczny — obejmuje człowieka w aspekcie somatycznym, psychicznym i społecznym. W wielu badaniach nad jakością życia uzależnioną od stanu zdrowia unika się definiowania pojęcia, a jedynie wylicza się składniki, które to pojęcie zawiera. Czynniki uwzględniane w szacowaniu jakości życia to:

1. czynniki fizyczne, takie jak:

— ból i dyskomfort,

- energia i zmęczenie,

- aktywność seksualna,

- sen i odpoczynek,

- funkcje sensoryczne;

2. stan psychiczny, wyznaczony przez:

- ból i dyskomfort,

- energię i zmęczenie,

- aktywność seksualną,

- sen i odpoczynek,

- funkcje sensoryczne;

3. stopień niezależności:

- niezależność ruchowa,

— aktywność na co dzień,

— brak uzależnienia od środków medycznych lub innych,

- zdolność porozumiewania się,

— zdolność do pracy;

4. relacje społeczne:

- osobiste więzi,

- wsparcie społeczne,

- zachowania wspierajace innych;

5. środowisko:

- środowisko domowe,

- wolność i bezpieczeństwo fizyczne,

— zadowolenie z pracy,

— zasoby finansowe,

- opieka zdrowotna i socjalna,

— możliwość wypoczynku;

6. wymiar duchowy:

— przekonania osobiste — najczęściej przekonania, wierzenia i praktyki religijne.

${ }^{2}$ J. Trzebiatowski, Jakość życia w perspektywie nauk społecznych i medycznych - systematyzacja ujęć definicyjnych, „Hygeia Public Health” 46 [1] (2011), s. 25-31.

Studia Philosophica Wratislaviensia 13, 2018 z. 4, (C) for this edition by CNS 
WHO określa jakość życia jako sposób oceniania przez jednostki ich pozycji życiowej zależny od oceny zdrowia fizycznego, stanu emocjonalnego, samodzielności życiowej i niezależności od otoczenia, a także relacji z otoczeniem i osobistych przekonań ${ }^{3}$.

W medycynie nie wypracowano jednej definicji jakości życia, jest ich wiele. Zwykle mają charakter operacyjny, każda dziedzina medycyny (onkologia, interna, reumatologia, gerontologia, psychiatria) może definiować to pojęcie na swój użytek. Pomimo że pojęcie jakości życia jest wieloznaczne (zawiera treści opisowe i oceniające), współczesna medycyna i polityka społeczna nie mogą się bez niego obejść.

Pojęcie to ma szerokie zastosowanie, służy ono do ${ }^{4}$ :

— badania zdrowotnych i pozazdrowotnych konsekwencji stanów chorobowych (sprawność fizyczna, psychiczna, intelektualna; samodzielność życiowa, udział w życiu społecznym);

— oceny medycznych i pozamedycznych efektów opieki zdrowotnej i interwencji lekarskiej;

— ustalenia zależności między nadziejami i oczekiwaniami ludzi wobec medycyny i służby zdrowia a ich osobistymi doświadczeniami;

- wypracowania programów rehabilitacji medycznej, zawodowej, psychospołecznej ludzi dotkniętych problemami zdrowotnymi (choroby przewlekłe - epilepsja, reumatyczne, nowotwory, cukrzyca, astma);

- podjęcia decyzji, do kiedy życie ludzkie ma być podtrzymywane, przerwane (aborcja, eutanazja);

- ustalenia, w jakich okolicznościach można powołać do istnienia lub uniemożliwić zaistnienie życia ludzkiego (antykoncepcja, sterylizacja, aborcja);

- rozstrzygnięcia, jakie kryteria usprawiedliwiaja interwencje mające na celu modyfikację natury biologicznej człowieka (prokreacja medycznie wspomagana, klonowanie, eugenika);

— wypracowania programów polityki społecznej w zakresie ekologii, zdrowia publicznego, demografii.

Liczne badania jakości życia uzależnionej od zdrowia wykazały, że duże znaczenie ma tu wsparcie społeczne i struktura społeczna (stopień integracji społecznej) — to one pozwalają redukować stres, umożliwiają adaptację fizyczną, psychiczną i społeczną pacjentów, ludzi chorych. Z tych powodów nawet ludzie ciężko chorzy postrzegają swoje życie jako dobre, satysfakcjonujące, natomiast zdrowi mogą znacznie niżej oceniać swoją sytuację życiową. Sprawa oceny jakości życia nie jest prosta, wiadomo jednak, że obiektywne warunki życia (w tym obiektywne kryteria stanu zdrowia) nie są prostym i jedynym wskaźnikiem zaspokojenia ważnych potrzeb ludzkich i poczucia satysfakcji z życia.

Najbardziej popularnym narzędziem badającym jakość życia jest Short-Form Health Survey. W Polsce najczęściej stosowane były takie kwestionariusze, jak:

\footnotetext{
${ }^{3}$ Podaję za: I. Cymerman, Doświadczanie jakości życia po przeszczepie - perspektywa fenomenologiczno-hermeneutyczna, Olsztyn 2007, s. 39.

${ }^{4}$ B. Tobiasz-Adamczyk, Jakość życia..., s. 34; oraz W.T. Reich, Quality of Life, [w:] Encyclopedia of Bioethics, W.T. Reich (ed.), vol. 2, New York 1978, s. 829-831.
} 
(SF-36), (AQLQ), (WHOQOL)-BREFF5 . Wiele dostępnych na świecie kwestionariuszy nie było walidowanych do warunków polskich. Poniżej wymieniam przykłady stosowanych narzędzi do pomiaru jakości życia ${ }^{6}$.

\section{Short-Form Health Survey (SF-36)}

Skala składa się z 36 pytań. Kwestionariusz poddaje analizie w ośmiostopniowej skali profil funkcjonalny zdrowia i dobrego samopoczucia, jak również ocenę psychometryczną opartą na fizycznym i psychicznym stanie zdrowia respondenta. Jakość życia na podstawie fizycznego stanu zdrowia mierzona jest za pomocą następujących wskaźników: funkcjonowanie fizyczne, odczuwanie bólu, ogólny stan zdrowia. Natomiast jakość życia na podstawie zdrowia psychicznego mierzona jest poprzez: aktywność funkcjonowania w społeczeństwie, stan emocjonalny oraz psychiczny.

\section{Asthma Quality of Life Questionnaire (AQLQ)}

Jest to kwestionariusz autorstwa prof. Elizabeth Juniper z Uniwersytetu McMastera w Kanadzie. Składa się z 32 pytań do samodzielnego wypełnienia przez respondenta lub wypełnienia przez lekarza podczas wywiadu. Celem jest ocena wpływu procesu terapeutycznego na codzienną aktywność chorego na astmę. Za pomoca kilkustopniowej skali można dokonać oceny: stopnia aktywności fizycznej, unikania czynników wpływających na duszność, występowania objawów nocnych, lęku, wpływu choroby na codzienną aktywność w społeczeństwie. Kwestionariusz rekomendowany jest do stosowania w badaniach klinicznych.

\section{The World Health Organization Quality of Life (WHOQOL)-BREFF}

Jest to kwestionariusz służący ocenie psychometrycznej jakości życia. W pięciostopniowej skali analizuje on stan emocjonalny (radość z życia, możliwość realizacji zainteresowań, relacje z najbliższym otoczeniem, doświadczanie negatywnych odczuć, takich jak: lęk, rozpacz, przygnębienie, depresja) oraz stan fizyczny respondenta (zaburzenia snu, wydolność w życiu codziennym, poziom energii umożliwiającej funkcjonowanie w społeczeństwie).

\section{Euro-Quality of Life Questionnaire (EQ-5D)}

Kwestionariusz ten stosowany jest u osób powyżej 12. roku życia. Celem jest analiza stanu zdrowia przy uwzględnieniu pięciu kategorii: troska o siebie, sprawność fizyczna, codzienna aktywność (praca, obowiązki domowe, nauka, wypoczynek, rodzina), lęk/depresja oraz ból/dyskomfort.

${ }^{5}$ Wzór kwestionariusza SF-36 podają J. Tylka, R. Piotrowicz, Kwestionariusz oceny jakości życia wersja polska, „Kardiologia Polska” 67 [10] (2009), s. 1166-1169.

${ }^{6}$ A. Kłak, M. Mińko, D. Siwczyńska, Metody kwestionariuszowe badania jakości życia, „Problemy Higieny i Epidemiologii” 93 [4] (2012), s. 632-638. 
Z kolei w szacowaniu kosztów opieki zdrowotnej i podziale środków medycznych często stosuje się metody $Q A L Y, D A L Y^{7}$.

\section{QALY (Quality-Adjusted Life Year — liczba lat życia skorygowana jego jakościa)}

Metoda ta stanowi jedną z prób analizy użyteczności postępowania medycznego w systemie ochrony zdrowia. Opiera się na liczbie lat zyskanej (lub przewidywanej) dzięki danej interwencji medycznej oraz na subiektywnym odczuciu satysfakcji z życia na skali: śmierć (0) — pełne zdrowie (1). Mnoży się oba współczynniki i uzyskuje wskaźnik efektu terapeutycznego.

Na przykład życie pacjenta można wydłużyć o 10 lat, lecz pacjent wolałby żyć 1 rok w zdrowiu niż w obecnym stanie (życie ma dla niego wartość 0,1 ). Wydłużenie życia chorego o 6 lat przy jego jakości 0,3 daje zysk 1,8 QALY. Wydłużając życie o mniejszą liczbę lat, ale za to bardziej poprawiając jego jakość, można uzyskać wyższy wskaźnik $Q A L Y$. Jest to sposób umożliwiający porównywanie różnych procedur medycznych. Im wyższa wartość $Q A L Y$, tym procedura jest korzystniejsza. Jak wskazuje Kazimierz Szewczyk ${ }^{8}$, jeśli respondenci zamieniliby 10 lat życia z niewydolnością nerek (i koniecznością dializowania) na 8 lat życia w pełnym zdrowiu, to ocenili efekt terapeutyczny dializy na 0,8 . Jeśli roczne koszty dializowania wynoszą 75000 zł, to podzielone przez 0,8 wskazują efektywność kosztową, która wynosi 93750 zł na $1 Q A L Y$.

\section{DALY (Disability-Adjusted Life Year — liczba lat życia skorygowana niepetno- sprawnościa)}

Ta metoda stosowana jest do określenia stanu zdrowia społeczeństwa. Wyraża łącznie lata życia utracone wskutek przedwczesnej śmierci bądź uszczerbku na zdrowiu w wyniku urazów, wypadków, chorób. Wskaźnik $D A L Y$ służy do pomiaru obciążenia chorobami w badanej populacji (wyróżnionej ze względu na wiek, płeć, region). Przydaje się przy identyfikacji głównych przyczyn chorób oraz przy rozdzielaniu środków na działania profilaktyczne. Pozwala także na ocenę skuteczności podejmowanych działań. Jeden $D A L Y$ oznacza utratę 1 roku w zdrowiu. Przyczyną tej utraty może być przedwczesna umieralność lub inwalidztwo. Wskaźnik DALY pozwala dokładnie śledzić i rejestrować skutki chorób (upośledzenie, niepełnosprawność) bądź okaleczeń wskutek urazów. Analizy z użyciem $D A L Y$ ujawniają również informacje o niezdrowych nawykach (używki, brak ruchu itd.) i to, jakim są one obciążeniem dla społeczeństwa. Wskaźnik wykorzystywany jest przez WHO i inne instytucje zajmujące się zdrowiem publicznym do określenia wpływu stanu zdrowia obywateli na sytuację społeczną i gospodarczą społeczeństwa. Wskaźnik ten, w przeciwieństwie do $Q A L Y$, pokazuje coś niekorzystnego („brzemię życia związanego z chorobą" ${ }^{\prime \prime}$ ) i im jest wyższy, tym gorszy jest stan zdrowia.

7 A. Ostrzyżek, J.T. Marcinkowski, Jakość życia jako pozytywny wskaźnik zdrowia, „Hygeia Public Health" 47 [4] (2012), s. 408-411.

${ }^{8}$ K. Szewczyk, Bioetyka, t. 2: Pacjent w systemie opieki zdrowotnej, Warszawa 2009, s. 25.

${ }^{9}$ T. Hope, J. Savulescu, Czy ustugi medyczne maja być darem czy towarem?, [w:] Dylematy bioetyki, A. Alichniewicz, A. Szczęsna (red.), Łódź 2001, s. 205. 
Zarówno $Q A L Y$, jak i $D A L Y$ są krytykowane za uproszczone ujęcie jakości życia, dobra pacjenta i sprawiedliwego podziału środków medycznych ${ }^{10}$.

\section{Spór o jakość życia w bioetyce}

Bioetyka to istniejąca od lat sześćdziesiątych XX wieku, dynamicznie rozwijająca się dziedzina wiedzy i praktyki społecznej ${ }^{11}$. Zajmuje się etycznymi aspektami nauk medycznych w kontekście ich kulturowych, ekonomicznych i prawnych uwarunkowań. Obejmuje etykę medyczną i etykę badań naukowych. Nie wypracowano jednego powszechnego rozumienia przedmiotu bioetyki, trwaja spory o sposoby uprawiania tej dyscypliny, klasyfikacje głównych stanowisk, jej związki z innymi sferami życia społecznego (prawo, polityka, ekonomia, socjologia). Najogólniej można powiedzieć, że jest etyką normatywną, a jej głównym zadaniem jest analiza problemów i normowanie działań w obszarze ingerencji w życie ludzkie w warunkach, jakie stwarza współczesna cywilizacja (problemy początków ludzkiego życia, nowoczesne terapie, problemy umierania i śmierci, opieki zdrowotnej).

Świętość czy jakość życia?

Spory o to, jak oceniać życie ludzkie, szczególnie w sytuacji zagrożenia, braku wystarczających dla wszystkich potrzebujących środków medycznych, stosowania nowych inwazyjnych metod leczenia, możliwości podtrzymywania życia ludzkiego na poziomie wegetatywnym, są nieuchronne. Życie ludzkie należy w kulturze europejskiej do wartości szczególnie cenionych — istnieje głęboko zakorzenione przekonanie, że życie ludzkie (w szczególności życie ludzi niewinnych) jest święte, nietykalne (inaczej mówiąc: ma wartość bezwzględną — stałą i niezależną od fazy czy poziomu istnienia). Jednak słuszność tego przekonania jest coraz częściej kwestionowana - przyczyniają się do tego zarówno charakter zmian współczesnej cywilizacji (tempo zmian warunków egzystencji jednostek i całych społeczeństw), zderzenie się odmiennych kultur operujących swoimi koncepcjami sensu świata i życia (zderzenie antropocentryzmu i biocentryzmu na poziomie religii i systemów filozoficznych), jak i kłopoty z realizacją nakazu bezwzględnej ochrony życia ludzkiego $^{12}$. Najpełniej i najmocniej etyka świętości życia jest eksponowana w personalizmie chrześcijańskim, dokładniej mówiąc — w jego katolickiej odmianie ${ }^{13}$. Z kolei najbardziej znanym rzecznikiem etyki jakości życia jest Peter Singer, który od

${ }^{10}$ Ibidem, s. 199-225; K. Szewczyk, Bioetyka, t. 2, s. 25-26.

11 K. Szewczyk: Bioetyka, t. 1. Medycyna na granicach życia, Warszawa 2009, s. 34-74.

12 H. Kuhse, The Sanctity-of-Life. Doctrine in Medicine, Oxford 1987; H. Kuhse, P. Singer, Should the Baby Live?, Oxford 1985; P. Singer, O życiu i śmierci. Upadek etyki tradycyjnej, tłum. A. Alichniewicz, A. Szczęsna, Warszawa 1997.

13 Protestantyzm, choć także zakłada świętość życia ludzkiego, skłonny jest nadawać etyce sytuacyjny charakter. W efekcie rozstrzygnięcia tu proponowane przypominają raczej etykę jakości życia. Por. P. Ramsey, Pacjent jest osoba, tłum. S. Łypacewicz, Warszawa 1977, s. 13-14; J. Fletcher, Morals and Medicine, Princeton 1979; Medycyna a prawa człowieka: normy i zasady prawa międzynarodowego, etyki oraz moralności katolickiej, protestanckiej, żydowskiej, muzułmańskiej i buddyjskiej, tłum. I. Kaczyńska, Warszawa 1996. 
wielu lat stara się wykazać, że etyka świętości życia jest anachroniczna, nie może rozwiązać problemów pojawiających się we współczesnej medycynie, a jej stosowanie prowadzi do ludzkich tragedii. Trzeba, jak twierdzi, kierować się etyką jakości życia, która wykazuje więcej współczucia, jest bardziej zgodna z poglądami ludzi w sprawach życia i śmierci i bardziej precyzyjnie wskaże zakres obowiązków wobec chorych, cierpiacych, umierających czy znajdujących się w beznadziejnym stanie.

W pewnym zakresie można przyznać Singerowi rację — to prawda, że w poglądach moralnych i w refleksji etycznej widać, szczególnie w czasie ostatnich lat, zmiany. Często podważa się zasadę świętości ludzkiego życia, ogranicza jej zakres wobec niektórych ludzi, rozszerza się ją także na inne istoty, czyni liczne wyjątki, coraz częściej jawnie ocenia się jakość życia — widać to w wypowiedziach bioetyków, lekarzy oraz w praktyce lekarskiej i moralności potocznej. Powody są różne. Kłopoty z utrzymaniem tezy o jednakowej wartości życia ludzkiego związane są z zastosowaniem techniki w medycynie, rozwojem nowych metod terapii, wzrostem długości życia i oczekiwaniem, że będzie ono jakościowo wysokie, trudnościami z podziałem ograniczonych środków medycznych. Czy to jednak wystarczy, by upadła etyka (i moralność) tradycyjna, czy cała ta konstrukcja rzeczywiście legnie w gruzach, jak twierdzi Singer? Być może tak — o ile jej fundamentem jest jedynie zasada świętości ludzkiego życia. Przemiany w moralności są nieuniknione, ale czy będą aż tak rewolucyjne, nagłe, trudno powiedzieć.

Jednocześnie trzeba podkreślić, że zwolennicy etyki świętości życia ludzkiego mają liczną reprezentację, ich głos jest także mocny i radykalny we wnioskach, do jakich dochodzą ${ }^{14}$. Poza tym za utrzymaniem zasady świętości życia ludzkiego przemawiają względy psychologiczne. Nawet jeśli zasada ta jest często łamana, ludzie wolą wierzyć, że należy ją utrzymać. Boją się, że wprowadzenie na jej miejsce zasady jakości życia może doprowadzić do nadużyć i zerwania zaufania między lekarzem a pacjentem — kto zaręczy, że ocena jakości życia ludzkiego zostanie dokonana obiektywnie (tylko na podstawie precyzyjnych kryteriów podmiotowości lub poziomu zdrowia mierzonego za pomocą kryteriów medycznych), a nie na podstawie innych, bardziej wieloznacznych kryteriów, na przykład miejsca człowieka w hierarchii społecznej, jego statusu majątkowego, zasług, wykształcenia? Należy w tym upatrywać, moim zdaniem, niechęci ludzi do uznania zasady jakości życia za podstawową zasadę, która ma kierować decyzjami w sprawie życia i śmierci ${ }^{15}$.

W medycynie i w bioetyce można zauważyć dwie przeciwstawne tendencje. Współcześnie przypisuje się życiu (a nie zdrowiu) szczególną wartość, zdają się to potwierdzać transplantacje i terapie o dużym stopniu ryzyka lub tak zwane terapie heroiczne. Z kolei entuzjazm dla genetyki, inżynierii genetycznej, klonowania może świadczyć, jak sądzę, o wadze, jaką współcześnie ludzie przykładają do jakości życia. Możliwości ratowania życia i leczenia są bardzo

${ }^{14}$ Ch.S. Swindoll, Świętość życia. Temat nieunikniony, tłum. J. Bartosik, Warszawa 1993; B.N. Nathanson, Ręka Boga, tłum. M. Sobolewska, Warszawa-Ząbki 1997; G. Marcel, Życie a sacrum, „Znak” 43 [437] (1991), s. 4-14; oraz A.J. Heschel, Wzorzec życia, „Znak” 43 [437] (1991), s. 92-97.

${ }^{15}$ D. Ślęczek-Czakon, Problem wartości i jakości życia w sporach bioetycznych. Katowice 2004, s. $233-236$. 
D. Ślęczek-Czakon, Pojęcie jakości życia

duże w porównaniu z przeszłością, ale — jak często się okazuje — ratowanie i przedłużanie życia łączy się z obniżeniem jego jakości, a dbałość o jakość prowadzi do negacji życia jako wartości bezwzględnej, świętej.

Kontrowersje w medycynie i etyce medycznej wokół sądów oceniających jakość życia są nieuniknione. Dotyczy to także możliwych konsekwencji dla medycyny, praktyki lekarskiej i życia społecznego. Można pytać, czy stosowanie pojęcia jakości życia doprowadzi do relatywizacji wartości ludzkiego życia i odrzucenia tezy o jego świętości, czy też deklaratywnie utrzyma się założenie o świętości ludzkiego życia z jednoczesnym jawnym i niejawnym stosowaniem kryteriów jakości (medycznych, ekonomicznych, etycznych) i coraz liczniejszymi korektami samej doktryny świętości życia. Trudno jednoznacznie na takie pytanie odpowiedzieć. Wydaje mi się, że bardziej prawdopodobna jest ta druga możliwość.

\section{Propozycja Beauchampa i Childressa}

Tom L. Beauchamp i James F. Childress, amerykańscy bioetycy, zajmują stanowisko nazywane teorią czterech zasad lub pryncypializmem ${ }^{16}$. Zasady, które uznają za podstawowe, wywodzą się z rozważnych sądów obecnych w moralności potocznej i z tradycji medycznej. Ich celem jest uszczegółowienie i wyważenie wspomnianych zasad tak, by opracować spójny system tez. Teoria czterech zasad składa się z różnych normatywnych składników — zasad, reguł, praw i cnót. Reguły, prawa i cnoty mają największe znaczenie dla etyki medycznej, ale zasady (czyli najogólniejsze normy) są kręgosłupem teorii.

Najogólniejsza struktura teorii czterech zasad wygląda następująco. Są cztery kategorie zasad moralnych (w innych teoriach mogą one być nazywane inaczej: jako prawa, cnoty, wartości). Zasady te są fundamentem etyki medycznej, a wynikają z rozważnych sądów moralnych. Wprowadzony $\mathrm{w}$ teorii podział na zasady i reguły nie jest ścisły — i zasady, i reguły odnoszą się do normatywnych uogólnień regulujących ludzkie działania. Można jednak założyć, że treść reguł jest bardziej szczegółowa, a ich zakres bardziej określony niż treść i zakres zasad. Zasady nie funkcjonują jako ścisłe dyrektywy postępowania w każdej sytuacji (to czynią raczej reguły). Zasady są tylko ogólnymi drogowskazami, pozostawiają nam wolną rękę w wydawaniu szczegółowych sądów w konkretnej sytuacji, wskazują też kierunek ustalania bardziej konkretnych reguł czy programów.

Za podstawowe zasady uznają:

1. szacunek dla autonomii — jest ona źródłem norm nakazujących poszanowanie dla woli autonomicznych osób podejmujących decyzję;

2. niekrzywdzenie - z niej wywodzimy normy zakazujące wyrządzanie krzywdy;

3. dobroczynność — jest podstawą zbioru norm nakazujących wyświadczanie dobra oraz maksymalizację nadwyżki zysków nad kosztami i ryzykiem;

4. sprawiedliwość — z niej wywodzimy zbiór norm nakazujących odpowiednią dystrybucję dobra, ryzyka, kosztów.

${ }^{16}$ T.L. Beauchamp, J.F. Childress, Zasady etyki medycznej, tłum. W. Jacórzyński, Warszawa 1996. 
Niekrzywdzenie i dobroczynność od dawna były głównymi zasadami w etyce medycznej, podczas gdy szacunek dla autonomii i sprawiedliwość długo były lekceważone, pojawiły się dopiero w XX wieku.

T.L. Beauchamp i J.F. Childress proponują wyważoną koncepcję jakości życia, odwołujaccą się do autonomii kompetentnych pacjentów, sprawiedliwości i korzyści, by ustalić, jakie środki medyczne są obowiązkowe, a jakie nieobowiązkowe. Autorzy, proponując zmianę dotychczasowej praktyki w sprawach środków podtrzymujacych życie, i tak interpretują zasady etyki medycznej, by liczyły się one z jakością życia. Przyznają jednak, że pojęcie jakości życia jest niejasne i trzeba je poddać ostrożnej analizie. Nie zgadzają się z Paulem Ramseyem, że należy odrzucić moralną treść tego zwrotu, a przyjąć jedynie interpretację medyczną. Ich zdaniem względy medyczne zawsze splecione są z kryteriami moralnymi — ustalenie, jakie środki medyczne są wskazane, jaka forma leczenia przyniesie korzyść pacjentowi, jest niemożliwe, jeśli nie ma się kryteriów dobrego życia i jeśli nie uwzględnia się zmiany poziomu jakości życia po zastosowaniu danej terapii.

Dotychczasowe tradycyjne w medycynie rozróżnienia dotyczące podtrzymywania życia według Beauchampa i Childressa nie nadają się do stosowania w warunkach autonomii pacjenta i jego praw. Proponują zastąpić je rozróżnieniem na środki obowiązkowe i nieobowiązkowe. W zależności od jakości życia można ich zdaniem wyznaczyć trzy zasadnicze linie postępowania w praktyce medycznej:

1. obowiązek leczenia (złem jest nieleczenie, ponieważ istnieją możliwości wyleczenia lub poprawy kondycji pacjenta);

2. możliwość leczenia: neutralna (leczenie nie jest wymagane ani zabronione) oraz ponadobowiązkowa (leczenie jest chwalebne, wiąże się z dodatkowym poświęceniem lekarza, lecz rezygnacja z niego nie będzie potępiana);

3. obowiązek nieleczenia (złem jest leczenie, ponieważ nie poprawi ono kondycji pacjenta, przyniesie jedynie cierpienia).

W ustaleniu, czy leczenie jest obowiązkowe, czy nieobowiązkowe, decyduje bilans kosztów, ryzyka i spodziewanych zysków. W wypadku pacjentów kompetentnych oni mają pierwszeństwo dokonania takiego bilansu i podjęcia decyzji o leczeniu bądź rezygnacji z terapii. Wobec pacjentów niekompetentnych trudno jest zastosować zasadę szacunku dla autonomii (nie znamy ich preferencji, gdyż nie mogli ich ujawnić bądź tego nie uczynili). W takiej sytuacji musimy odwołać się do zasady dobroczynności lub zasady niekrzywdzenia.

Obowiązek leczenia jest uchylony, a pacjent, lekarz lub opiekun pacjenta mogą podjąć decyzję o zaniechaniu leczenia, gdy:

- leczenie jest bezskuteczne lub bezcelowe (nie przyniesie pozytywnych zmian w stanie pacjenta) lub działania medyczne mają niskie prawdopodobieństwo powodzenia i wysokie prawdopodobieństwo wyrządzenia krzywdy;

— leczenie przynosi więcej uciążliwości niż korzyści — dotyczy to nie tylko pacjentów w stanie terminalnym, nawet jeśli pacjent nie umiera, nie ma obowiązku terapii, jeśli niedogodności z nią związane przyniosą pacjentowi więcej szkody niż pożytku.

Decyzje o niepodejmowaniu lub wycofaniu leczenia są zawsze dramatyczne. Nie wszystkie jednak decyzje o podjęciu czy kontynuowaniu terapii są uzasadnione, słuszne. 
Z zasady nieszkodzenia nie wynika obowiązek podtrzymywania życia biologicznego ani też obowiązek podjęcia czy kontynuowania terapii bez względu na ból, cierpienie i złe samopoczucie, jakie ona za sobą pociągnie. [...] [J]eśli jakość życia jest odpowiednio niska, a zastosowanie terapii czyni pacjentowi więcej szkody niż pożytku, niepodjęcie lub wycofanie leczenia jest usprawiedliwione ${ }^{17}$.

Beauchamp i Childress zdają sobie sprawę z niejasności pojęcia jakości życia, co więcej - uznają, że wyznaczenie obiektywnych, tylko medycznych (bez treści moralnych), kryteriów jakości życia jest niewykonalne. Pewni są jednak tego, że podtrzymywania biologicznej wegetacji nie można uznać za korzystne, jak też tego, że nie wolno utożsamiać jakości życia pacjenta z jakością czy wartością, jaką jego życie ma dla innych (społeczeństwa, rodziny). Za cechę nieistotną w ustalaniu jakości życia uznają umysłowy niedorozwój pacjenta. Decydujące w ustaleniu jakości życia pacjenta jest określenie jego najlepszego interesu. Pomimo nieostrości pojęcia jakości życia bioetycy sądzą, że najlepiej pozwala ono określić, które środki medyczne są obowiązkowe, a z których można zrezygnować.

Kierowanie się jakością życia wcale nie oznacza utraty szacunku dla życia ludzkiego i nie musi grozić zalegalizowaniem niekontrolowanej eutanazji dobrowolnej i niedobrowolnej — twierdzą autorzy. Obecne w polityce społecznej i medycynie metody oceny wartości ludzkiego życia oparte na analizach ekonomicznych oraz mierzeniu jakości życia, przyznają Beauchamp i Childress, mogą prowadzić do niepożądanych konsekwencji. Na liście zarzutów wobec metod oceny wartości i jakości życia umieszcza się najczęściej następujące kwestie:

- eksperci dokonujący analiz kosztów ze względu na korzyści, efektywność, czy też obliczający ryzyko ze względu na korzyści (chodzi o ustalenie priorytetów w ochronie zdrowia, zastosowaniu techniki medycznej) mogą być stronniczy takie analizy mają elitarny, antydemokratyczny charakter, służą interesom wąskich grup społecznych (preferuje się ludzi młodych, w mniejszym stopniu chorych, o większym prestiżu społecznym);

- kryterium lat życia o ustalonej jakości opiera się na subiektywnym rachunku użyteczności, przedkłada się tu długość życia nad liczbę indywidualnych istnień;

- techniki pomiaru przywiązują zbyt wielką uwagę do wartości ilościowych, a za małą do nieilościowych, takich jak uśmierzanie bólu i cierpienia — na przykład z punktu widzenia analizy ekonomicznej utrzymanie hospicjów jest nieefektywne i niekorzystne, gdyż analiza taka nie uwzględnia niewymiernych korzyści, takich jak umieranie z godnością czy złagodzenie cierpień;

- metody analityczne mogą przyczynić się do znieczulicy, zaniku uczuć moralnych, stępienia wrażliwości; operowanie językiem ekonomicznym może doprowadzić do zerwania tradycyjnych relacji między lekarzem i pacjentem.

Beauchamp i Childress są umiarkowanymi optymistami — nie lekceważą możliwych zagrożeń, mają jednak nadzieję, że zagrożenia te nie muszą przybierać katastroficznych rozmiarów. Techniki formalne, podkreślają, muszą mieć swoje granice zakreślone przez zasadę autonomii, dobroczynności i sprawiedliwości.

${ }^{17}$ T.L. Beauchamp, J.F. Childress, Zasady..., s. 227. 


\section{Wnioski}

Pojęcie jakości życia, choć stosunkowo niedawno stało się kategorią obecną w naukach społecznych i w polityce społecznej, jest coraz częściej stosowane w badaniach medycznych i w praktyce medycznej. Zrozumiałe jest i to, że w bioetyce stało się przedmiotem namysłu i ostrych sporów.

Postęp nauk medycznych, oprócz niekwestionowanych korzystnych skutków: zmniejszenia się śmiertelności niemowląt, wydłużenia średniej długości życia, sukcesów w leczeniu wielu chorób, doprowadził do możliwości przedłużania ludzkiego życia za wszelką cenę, poza granice rozsądku i humanitaryzmu. Zapewne przyczynił się do tego proces medykalizacji ${ }^{18}$ choroby i śmierci. Choć przyjmujemy, że wartość ludzkiego życia jest duża, często „trudno jest określić, co się na tę wartość składa, jak dalece jest ona uniwersalna i niezmienna, a jak bardzo stopniowalna i zależna od kontekstu społecznego"19. Zwykle aprobujemy bohaterskie czyny ratowania życia, potępiamy zaś te, które zmierzają do jego przerwania. W konkretnych sytuacjach mamy kłopot z zastosowaniem tych ogólnych norm dotyczących obrony życia ludzkiego - chodzi tu o takie interwencje w trwanie życia, które można określić jako uporczywe, heroiczne, ale daremne, bezużyteczne, bo nieprzynoszące korzyści choremu (szansa na ich skuteczność jest bliska zeru, choremu przysparza się cierpienia) ani innym ludziom (stosowanie kosztownych środków do ratowania, przedłużania jednego życia narusza zasady sprawiedliwości, bo nie pozwala na udzielenie skutecznej pomocy innym, lżej chorym). Podobne kłopoty mamy z określeniem: kiedy zrezygnować ze stosowania środków medycznych (wycofać je lub w ogóle nie stosować), które środki uznać za obowiązkowe (zwyczajne), a które za nadzwyczajne, czy jest jakaś różnica między działaniem a zaniechaniem w praktyce medycznej ${ }^{20}$.

Tendencja do przedkładania życia nad zdrowie we współczesnej medycynie i kulturze niewątpliwie istnieje. Lekarz ma być obrońcą życia, ratować życie (nawet za wszelką cenę) przy użyciu wszystkich dostępnych środków medycznych, co często prowadzi do terapii uporczywej (zwanej tė heroiczną), ale daremnej. Jedną z przyczyn takiego myślenia i działania jest to, że człowiek uwierzył w swoją moc zapanowania nad koniecznościami przyrodniczymi (w tym nad śmiercią). Wiarę tę nadal podsyca rozwój nauki i techniki, szczególnie nowoczesne metody leczenia, inżynieria genetyczna obiecująca osiągnacć nieśmiertelność lub przynajmniej znacznie wydłużyć ludzkie życie. W takim ujęciu życie jest wartością najwyższą, autoteliczną, choroba i śmierć są złem, z którym należy walczyć. Nie jest to jednak tendencja jedyna — w latach sześćdziesiątych XX wieku pojawił się

${ }^{18}$ Przez medykalizację choroby i śmierci rozumie się to, że choroba i śmierć stały się obszarem badań i działań medycznych. To lekarz jest ekspertem od diagnozy, leczenia, profilaktyki zdrowotnej i umierania. Sam proces leczenia jest ważniejszy niż troska o ludzi, a postawa walki z chorobą prowadzi często do terapii uporczywej, heroicznej. Śmierć traktuje się jako porażkę medycyny, proces leczenia i umierania zostaje ,zamknięty" w szpitalu.

${ }^{19}$ A. Ostrowska, Śmierć w doświadczeniu jednostki i społeczeństwa, Warszawa 1997, s. 66.

${ }^{20}$ Nie są to pytania akademickie, stawiają je sami lekarze. Por. Ch. Barnard, Godne życie, godna śmierć, tłum. J.K. Kelus, Warszawa 1996; J. Bréhant, Thanatos. Chory i lekarz w obliczu śmierci, tłum. U. Sudolska, Warszawa 1993. 
D. Ślęczek-Czakon, Pojęcie jakości życia

drugi wyraźny nurt kładący nacisk nie na bezwzględną wartość życia, lecz na jego jakość i domagający się prawa człowieka do współuczestniczenia w decyzjach dotyczących życia i śmierci. Rzecznicy tego nurtu żądają, aby na nowo określić zadania medycyny. Sądzą, że należy to zrobić i w imieniu lekarzy, na których nałożono zbyt wiele obowiązków wobec życia, i w imieniu pacjentów ubezwłasnowolnionych podczas hospitalizacji. Medycyna w tym ujęciu ma powrócić do tradycyjnych zadań leczenia i uśmierzania bólu — ma czuwać nad całością życia pacjenta, życia takiego, jakiego on jeszcze pragnie.

Tak więc, z jednej strony, stosowanie pojęcia jakości życia jest nieuchronne (z różnych powodów — ekonomicznych, racjonalnego i sprawiedliwego podziału ograniczonych środków medycznych, szacunku dla autonomii pacjenta i jego praw), z drugiej jednak budzi zastrzeżenia etyczne.

\section{Bibliografia}

Barnard Ch., Godne życie, godna śmierć, tłum. J.K. Kelus, Warszawa 1996.

Beauchamp T.L., Childress J.F., Zasady etyki medycznej, tłum. W. Jacórzyński, Warszawa 1996.

Bréhant J., Thanatos. Chory i lekarz w obliczu śmierci, tłum. U. Sudolska, Warszawa 1993.

Cymerman I., Doświadczanie jakości życia po przeszczepie - perspektywa fenomenologiczno-hermeneutyczna, Olsztyn 2007.

Fletcher J., Morals and Medicine, Princeton 1979.

Heschel A.J., Wzorzec życia, „Znak” 43 [437] (1991), s. 92-97.

Hope T., Savulescu J., Czy usługi medyczne maja być darem czy towarem?, [w:] Dylematy bioetyki, A. Alichniewicz, A. Szczęsna (red.), Łódź 2001.

Kłak A., Mińko M., Siwczyńska D., Metody kwestionariuszowe badania jakości życia, „Problemy Higieny i Epidemiologii” 93 [4] (2012), s. 632-638.

Kuhse H., The Sanctity-of-Life. Doctrine in Medicine, Oxford 1987.

Kuhse H., Singer P., Should the Baby Live?, Oxford 1985.

Marcel G., Życie a sacrum, „Znak” 43 [437] (1991), s. 4-14.

Medycyna a prawa człowieka: normy i zasady prawa międzynarodowego, etyki oraz moralności katolickiej, protestanckiej, żydowskiej, muzułmańskiej i buddyjskiej, tłum. I. Kaczyńska, Warszawa 1996.

Nathanson B.N., Ręka Boga, tłum. M. Sobolewska, Warszawa-Ząbki 1997.

Ostrowska A., Śmierć w doświadczeniu jednostki $i$ społeczeństwa, Warszawa 1997.

Ostrzyżek A., Marcinkowski J.T., Jakość życia jako pozytywny wskaźnik zdrowia, „Hygeia Public Health” 47 [4] (2012), s. 408-411.

Ramsey P., Pacjent jest osoba, tłum. S. Łypacewicz, Warszawa 1977.

Reich W.T., Quality of Life, [w:] Encyclopedia of Bioethics, W.T. Reich (ed.), vol. 2, New York 1978.

Singer P., O życiu i śmierci. Upadek etyki tradycyjnej, tłum. A. Alichniewicz, A. Szczęsna, Warszawa 1997.

Swindoll Ch.S., Świętość życia. Temat nieunikniony, tłum. J. Bartosik, Warszawa 1993. 
Szewczyk K., Bioetyka, t. 1: Medycyna na granicach życia, Warszawa 2009.

Szewczyk K., Bioetyka, t. 2: Pacjent w systemie opieki zdrowotnej, Warszawa 2009. Ślęczek-Czakon D., Problem wartości i jakości życia w sporach bioetycznych, Katowice 2004.

Tobiasz-Adamczyk B., Jakość życia w naukach społecznych i medycynie. „Sztuka Leczenia" 2 (1996), s. 33-40.

Trzebiatowski J., Jakość życia w perspektywie nauk społecznych i medycznych systematyzacja ujęć definicyjnych, „Hygeia Public Health” 46 [1] (2011), s. 25-31.

Tylka J., Piotrowicz R., Kwestionariusz oceny jakości życia - wersja polska, „Kardiologia Polska" 67 [10] (2009), s. 1166-1169.

\section{The concept of the quality of life: The medical and the bioethical aspect}

\section{Summary}

The concept of the quality of life initially contained mainly objective indicators. It was only later that it was extended so as to include the subjective ones as well. Upon its transfer from its original medical context into the social sciences, the concept of the quality of life has inspired a new approach to sick persons. It is now acknowledged that it is not enough to merely prolong a life. It also has to meet the standards generally recognized by active, healthy people. In the assessment of the quality of life both objective (state of human health and socio-economic status) and subjective (satisfaction with life and perception of each other) indicators are used. It is used, among other things, to evaluate the effects of medical and non-medical health care and medical intervention. In bioethics, it is noted that the term diminishes the value of human life. The methods used to assess the value of human life based on economic analysis and the measuring of the quality of life can lead to undesirable consequences. Conclusion: on the one hand, the estimation of the quality of life is imminent for various reasons; on the other hand, however, it raises ethical objections.

Keywords: life, value, ethics, bioethics 